\title{
OPEN Spatiotemporal variation of nitrate concentrations in soil and groundwater of an intensely polluted agricultural area
}

\author{
Kei Nakagawa ${ }^{1 凶}$, Hiroki Amano² ${ }^{2}$ Magnus Persson ${ }^{3}$ \& Ronny Berndtsson ${ }^{4}$
}

Nitrate pollution in groundwater is a serious problem in many parts of the world. However, due to the diffuse and common spatially over-lapping character of potential several non-point pollution sources, it is often difficult to distinguish main nitrate sources responsible for the pollution. For this purpose, we present a novel methodology applied to groundwater for an intensely polluted area. Groundwater samples were collected monthly from April 2017 to March 2018 in Shimabara City, Nagasaki, Japan. Soil samples were collected seasonally at soil surface and $50 \mathrm{~cm}$ depth at 10 locations during the same period. Sequential extraction by water and extract agents was performed using calcium phosphate for anions and strontium chloride for cations. Mean nitrate concentration in groundwater close to a livestock waste disposal site (hereinafter called "LWDS") was $14.2 \mathrm{mg} \mathrm{L}^{-1}$, which is exceeding Japanese drinking water standards $\left(10 \mathrm{mg} \mathrm{L}^{-1}\right)$. We used coprostanol concentration, which is a fecal pollution indicator, to identify pollution sources related to livestock waste. For this purpose, we measured coprostanol $(5 \beta)$ and cholestanol $(5 \alpha)$ and then calculated the sterol ratio $(5 \beta /(5 \beta+5 \alpha))$. The ratios for three groundwater sampling sites were $0.28,0.26$, and 0.10 , respectively. The sterol ratios indicated no pollution $(<0.3)$. However, the detection of coprostanol originating from animal and human waste showed that groundwater was clearly affected by this pollution source. Nitrate levels in the soil were relatively high in samples collected close to the LWDS and coprostanol contents were affected by livestock waste. Soil and groundwater nitrate concentrations displayed a complex but strong relationship. Nitrate contents were shown to be transported downstream from source areas in both soil and groundwater.

Groundwater polluted by nitrate is a common problem leading to negative human health effects. World Health Organization recommends a maximum of $50 \mathrm{mg} \mathrm{L}^{-1}$ of nitrate $\left(\mathrm{NO}_{3}^{-}\right)$in drinking water ${ }^{1}$. In general, nitrate pollution in groundwater is often related to animal husbandry and heavy use of soil fertilizers. To improve the understanding of the fate and transport of nitrate and possible remediation measures, research is needed on new methods to distinguish different spatiotemporal nitrate sources to soil and groundwater. Many studies have focused on nitrate contents in groundwater ${ }^{2-8}$ and soil ${ }^{5,6,9-13}$. Modeling studies indicate that groundwater vulnerability to nitrate pollution can be explained by a complex set of different hydrogeologic variables such as depth to water table, net recharge, aquifer and soil media, topography, impact of the vadose zone, and hydraulic conductivity ${ }^{14}$. Besides this, the spatiotemporal variability of potential pollutant sources creates a second superimposed complexity. In practical applications it is therefore, difficult to distinguish fate and transport properties of nitrate from different overlapping pollutant sources. Similarly, potential remediation techniques are hampered by this lack of knowledge. Thus, it is important to develop new methods that can be tested on various experimental areas and observations of nitrate concentrations combined with transport modeling to efficiently evaluate future environmental effects and potential remediation alternatives ${ }^{15,16}$.

Shimabara City, Nagasaki, Japan, depends solely on groundwater for its public water supply. The city has been monitoring nitrate-nitrogen $\left(\mathrm{NO}_{3}-\mathrm{N}\right)$ concentration in public water wells since 1975. In general, $\mathrm{NO}_{3}-\mathrm{N}$

\footnotetext{
${ }^{1}$ Institute of Integrated Science and Technology, Nagasaki University, 1-14 Bunkyo-machi, Nagasaki 852-8521, Japan. ${ }^{2}$ Department of Kyushu Liberal Arts Education, Tokai University, 9-1-1 Toroku, Higashi-ku, Kumamoto 862-8652, Japan. ${ }^{3}$ Division of Water Resources Engineering, Lund University, Box 118, 22100 Lund, Sweden. ${ }^{4}$ Division of Water Resources Engineering, Centre for Advanced Middle Eastern Studies, Lund University, Box 118, 22100 Lund, Sweden. ${ }^{\circledR}$ email: kei-naka@nagasaki-u.ac.jp
} 
levels in the wells have continuously increased over the years. Recently, the $\mathrm{NO}_{3}-\mathrm{N}$ concentrations exceeded the Japanese drinking water standard of $10 \mathrm{mg} \mathrm{L}^{-1}$ in some wells. High nitrate levels in groundwater have been observed especially in the northern parts of the city for large groundwater depths $(>50 \mathrm{~m})^{17,18}$. High nitrate concentrations in surface water have also been reported ${ }^{19}$. In the northern parts of the city, the potential nitrate load was estimated in 1975 at about $258 \mathrm{~kg} \mathrm{~N}_{\text {year }}{ }^{-1} \mathrm{ha}^{-1}$. This figure increased to about $308 \mathrm{~kg} \mathrm{~N}_{\mathrm{Near}}^{-1} \mathrm{ha}^{-1}$ in 1985 , then reached $436 \mathrm{~kg} \mathrm{~N}_{\text {year }}{ }^{-1} \mathrm{ha}^{-1}$ in 1995. In 2010, the load was estimated at $455 \mathrm{~kg} \mathrm{~N}_{\text {year }}{ }^{-1} \mathrm{ha}^{-1}$, which is 1.8 times that of $1975^{20}$.

As mentioned above, high nitrate concentration in drinking water can affect human health and for infants there is an elevated risk of methemoglobinemia disease. Even though nitrate concentrations may not pose a fatal threat to humans, they do indicate the possible presence of other serious agricultural contaminants. Nitrate pollution is often related to agricultural activities and runoff from fertilizers or leachate from animal husbandry ${ }^{17-19}$. For this reason, evaluation of nitrate leaching from farmlands to surrounding water bodies and the environmental capacity of soils need to be assessed. It is evident that high nitrate concentration in soils is related to corresponding concentrations in surface and groundwater. However, these relationships are complex and not easy to quantify. Thus, although there have been previous studies on the nitrate in surface water and groundwater ${ }^{17-19}$, joint studies including soil nitrate and assessment of pollutant sources are still few.

Identifying the source of nitrate is a first step to unravel the complex relationships among groundwater, surface water, and soil. Previous studies have indicated that the spatial distribution of nitrate concentration in both surface and groundwater in Shimabara City is associated with the use of chemical fertilizers and livestock waste ${ }^{17,19}$. To identify individual nitrate pollution sources, isotopic nitrate data have proven successful ${ }^{21-24}$. However, some observations may not have a clear isotopic signature and not a clear association with a certain pollutant source ${ }^{21}$. To overcome this problem, coprostanol can be used to indicate fecal pollution and to distinguish between dominant nitrate pollution sources in groundwater ${ }^{25}$. Considering that the coprostanol content in groundwater is often quite low due to adsorption to soil and rock material, special analyses techniques are needed ${ }^{26}$. For this purpose, the sterol ratio between coprostanol and cholestanol may as well be investigated to indicate dominant nitrate pollution sources ${ }^{26}$. Coprostanol and sterol ratio are thus, parts of a comprehensive methodology that can be used to study the complex spatiotemporal nitrate variation and interactions between soil and groundwater. To the authors' knowledge, comprehensive studies on this are still rare in the research literature.

In view of the above, the main objective of this study is to present and test a novel methodology that can be used to improve the knowledge on the fate and transport of nitrate pollutants in complex and heavily polluted soils and groundwater. For this purpose, we investigated coprostanol content in soil, and sterol ratio in groundwater in the study area. A further objective was to investigate the relationships between soil, surface water, and groundwater in terms of nitrate concentration and to improve the understanding of nitrate dynamics in the area. To accomplish these objectives, we collected soil and groundwater samples close to a previously used livestock waste disposal site (LWDS) that was in use from 2000 and from downstream areas. We then used data obtained from previous studies ${ }^{17,19}$ to assess the nitrate dynamics of the area in soil and water since the LWDS is a possible main source of pollution. The LWDS has been in use during a prolonged period from 2000 to 2006 and nitrate is likely to remain in the soil due to slow natural attenuation, affecting both surface and groundwater downstream of the site. Thus, there is a possibility to monitor nitrate pollutants from the LWDS site using coprostanol as a tracer and map mixing and transport dynamics in the soil and water phase. The suggested novel methodology can potentially give us new insights of nitrate pollution fate and transport in the study area and new and improved knowledge on nitrate dynamics.

Study area. Shimabara City is located in the northeast part of the Shimabara Peninsula, Nagasaki, Japan (Fig. 1). The area of Shimabara City is $82.8 \mathrm{~km}^{2}$, occupying $18 \%$ of the Shimabara Peninsula. Shimabara City lies on the alluvial fan that spreads as a gentle slope from the Mt. Fugendake in the center of Shimabara Peninsula. The geology is formed by volcanic deposits composed of andesite, dacite, and tuff breccia. Upland agricultural areas are concentrated to the northern part of Shimabara City (Fig. 1). The cultivation area is $18.5 \mathrm{~km}^{2}$ and comprises $22.3 \%$ of Shimabara City (2015). The livestock raised in the area is about 1000 milk cattle, 23,000 pig, and $1,030,000$ chicken (2015). Many livestock raising facilities are located in the upstream areas of the Nishikawa and Yuegawa Rivers. The study area has a humid subtropical climate with an annual mean temperature of $17.1^{\circ} \mathrm{C}^{27}$. The area received $1989 \mathrm{~mm}$ of precipitation in 2017 . Normally, the rainy season occurs during June and July and precipitation amount was $571.5 \mathrm{~mm}$ (2017) (28\% of annual amount that was less than usual).

The hydrogeology of the study area has been described by Murakami ${ }^{28}$. Figure 2 shows a geological cross section according to the A-A' line in Fig. 1. The figure was constructed using geological profiles from boreholes ${ }^{28}$. The northern parts of the peninsula present a gentle slope that form an alluvial fan from the Mt. Fugendake composed of volcanic rock. The basement rock (Kuchinotsu Layer), has a circular arc-shaped structure that is gently inclined toward the coast. Close to the coast, the basement rock is distributed between 10 and $100 \mathrm{~m}$ below mean sea level. A thick layer of Paleogene period shale is found in the lower part of the Kuchinotsu Layer (360 to $420 \mathrm{~m}$ below mean sea level). Rock on top of the Kuchinotsu Layer forming a foot of the mountain is called Pre-Unzen volcanic rock (Tatsuishi Layer). This consists of tuff breccia, tuff, and volcanic conglomerate. The thickness of this layer is 100-150 m, and the top parts are constituted of weathered rock and sand gravel layer, which forms an unconfined aquifer ${ }^{29}$. Soil of the lower parts contains a confined groundwater aquifer. In the layer above the Tatsuishi Layer, the groundwater is unconfined ${ }^{29}$. Above $300 \mathrm{~m}$ amsl, Unzen volcanic rock forms the mountain area. This mainly consists of hornblende-andesite that displays mature joints and splits. The Unzen volcanic rock is favorable for large groundwater recharge. Near the boundary with Pre-Unzen volcanic rock, groundwater discharges as springs to the soil surface. Alluvium deposits have mainly developed in limited areas of the lowland in the river basin. The central parts of the peninsula belong to a subsidence area called Unzen 


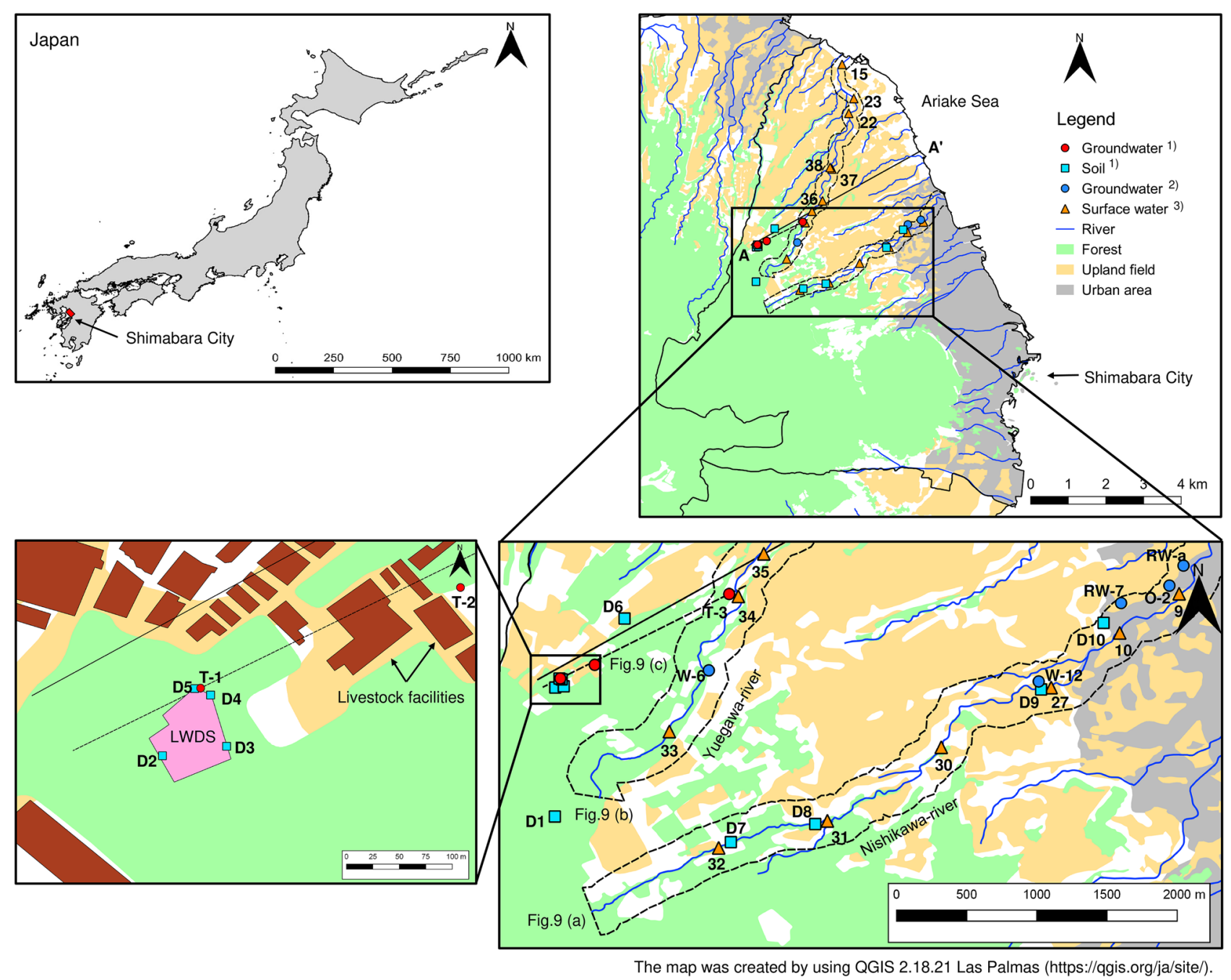

Figure 1. Study area. (1) this study. (2) Nakagawa et al. ${ }^{17}$, (3) Amano et al. ${ }^{19}$.

Graben. In these central parts, active volcanos such as the Mt. Fugendake are composed of hornblende-andesite and dacite that form steep mountain areas. As mentioned above, the Pre-Unzen volcanic rock is extensive and forms the major groundwater aquifer in Nagasaki Prefecture. Debris from the collapsed Mt. Mayuyama, located west of Shimabara city, is distributed in the urban area. Rainfall over this area infiltrates into deposits and becomes unconfined/confined groundwater that subsequently flows toward the Ariake Sea. Thus, artesian wells can be found close to the coastal line.

\section{Materials and methods}

Sampling and analysis. Sampling locations are shown in Fig. 1. To assess nitrate pollution sources, groundwater samples were collected once a month from three wells (T-1, T-2, and T-3) close to a livestock waste disposal site (LWDS) and the downstream area from April 2017 to March 2018. The depth of these wells is about $50 \mathrm{~m}$ from soil surface. Screens were installed in all wells. The groundwater in T-1 and T-2 are unconfined. On the other hand, as T-3 is an artesian well, it probably is connected to the lower parts of the Tatsuishi Layer. Soil samples were collected seasonally at soil surface and $50 \mathrm{~cm}$ depth at 10 locations. These locations included the LWDS that was used for secondary treatment of liquid manure (D2-D5), downstream of LWDS (D6), Nishikawa River Basin (D7-D10), and forest (D1) during the same period. The area of the LWDS is about $2000 \mathrm{~m}^{2}$, and its location is upstream in the Yuegawa River Basin (Fig. 1). Sampling around the LWDS was performed due to that the site is expected to be a main nitrate pollution source. For this reason, as well, soil samples were collected downstream of the LWDS (upland field). Two rivers (Yuegawa and Nishikawa River) and groundwater in this basin are heavily polluted by nitrate with a highest observed level of $27.5 \mathrm{mg} \mathrm{L}^{-1,17,19}$. We also collected soil samples from the Nishikawa River Basin as a comparison to Yuegawa River Basin. The LWDS was constructed by digging a $50 \mathrm{~cm}$ trench in the soil, installing a drainage pipe at a soil depth of $35 \mathrm{~cm}$, and then backfilling the trench. At time of construction, it was expected that most of the manure would be absorbed by the soil and excess water would be eliminated by evaporation and drainage. Thus, soil samples were collected from different soil depths. Sampling location T-1 is situated between the LWDS and the treatment plant for liquid waste. Operation of the treatment plant started in 2000 just after the Japanese livestock waste disposal law changed (1999). The 
A

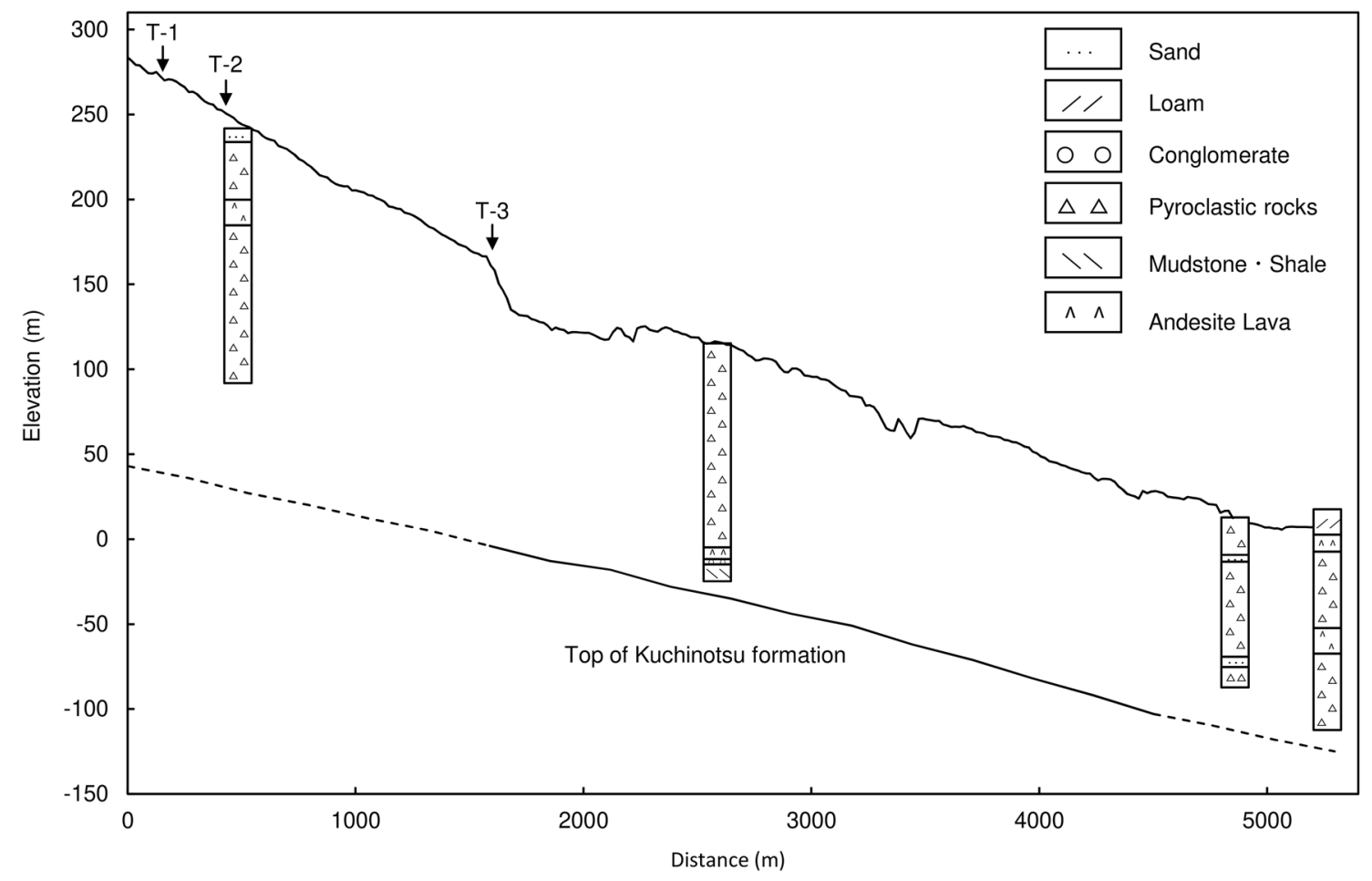

Figure 2. Geological cross section of line A-A' in Fig. 1.

LWDS was taken into use in 2000 to constitute a second treatment step added to the original treatment plant. Use of the LWDS was halted in 2006 because the treatment capacity of the plant was improved. Today, the effluent from the plant meets the standard $600 \mathrm{mg} \mathrm{L}^{-1}$ of treated waste water, but may exceed drinking water standard.

Portable meters (HORIBA D-51 and D-54) were used for measurements of $\mathrm{pH}$, oxidation-reduction potential (ORP), and electrical conductivity (EC). Dissolved oxygen (DO) was measured with a luminescence-based sensor ( $\mathrm{HACH} \mathrm{HQ30d).} \mathrm{HCO}_{3}{ }^{-}$was quantified using titration with $0.1 \mathrm{~N} \mathrm{HCl}$. These variables and water temperature were measured on-site. Sequential extraction by water and extract agents was performed for the soil samples. As extract agents, firstly water for both cations and anions, then calcium phosphate for anions and strontium chloride for cations were used. The major cations and anions $\left(\mathrm{Na}^{+}, \mathrm{NH}_{4}^{+}, \mathrm{K}^{+}, \mathrm{Mg}^{2+}, \mathrm{Ca}^{2+}, \mathrm{F}^{-}, \mathrm{Cl}^{-}, \mathrm{NO}_{2}^{-}\right.$, $\mathrm{NO}_{3}{ }^{-}$, and $\mathrm{SO}_{4}{ }^{2-}$ ) found in the water and extract samples were analyzed by ion chromatography (Metrohm 861 Advanced Compact IC). As well, coprostanol and cholestenol concentrations were monitored in the groundwater as indicators of fecal pollution. Sterols were extracted from all samples by liquid-liquid extraction with water-dichloromethane. After dehydration and concentration, the extract was converted to trimethylsilyl using bis (trimethylsilyl) trifluoroacetamide (BSTFA) followed by quantification utilizing gas chromatographymass spectroscopy (GC-MS) ${ }^{25}$. A more detailed description of the analysis method for sterols is described in Nakagawa et al. ${ }^{26}$.

Data analysis. To understand the temporal fluctuation of nitrate concentration, it is important to quantify precipitation events. Previous studies have shown that nitrate concentrations are clearly diluted after precipitation events ${ }^{17,18}$. Following previous studies, the relationship between precipitation and nitrate in groundwater and soil was evaluated using sterols as tracers. Precipitation data from Shimabara Observatory were downloaded from the Japan Meteorological Agency Website ${ }^{27}$.

We used coprostanol concentration as a tracer and to identify pollution sources related to livestock waste ${ }^{25,26}$. Elevated coprostanol concentration is a fecal pollution indicator. We measured coprostanol (5 $\beta$ ) and cholestanol $(5 \alpha)$ and then calculated the sterol ratio $(5 \beta /(5 \beta+5 \alpha))$. The sterol ratio was used as an indicator to evaluate fecal pollution at three levels: no pollution, uncertain, and certain pollution ${ }^{30}$. This suggested methodology has not been tested previously.

As mentioned above, the area close to the LWDS is expected to constitute a main pollution source. In order to evaluate a potential risk of nitrate pollution in groundwater from soil, nitrate concentrations in soil were converted to groundwater nitrate concentrations using a following regression equation suggested by Wang et al. ${ }^{9}$ :

$$
N_{g}=0.058 N_{s}+1.17
$$

where $N_{g}$ is nitrate concentration $\left(\mathrm{mg} \mathrm{L}^{-1}\right)$ in groundwater, and $N_{s}$ is nitrate concentration $\left(\mathrm{mg} \mathrm{kg}^{-1}\right)$ in soil.

To apply appropriate countermeasures against nitrate pollution, careful site examination is needed, thereby evaluating the relationship between soil, groundwater, and surface water. Finally, nitrate transport relationship 
(a)

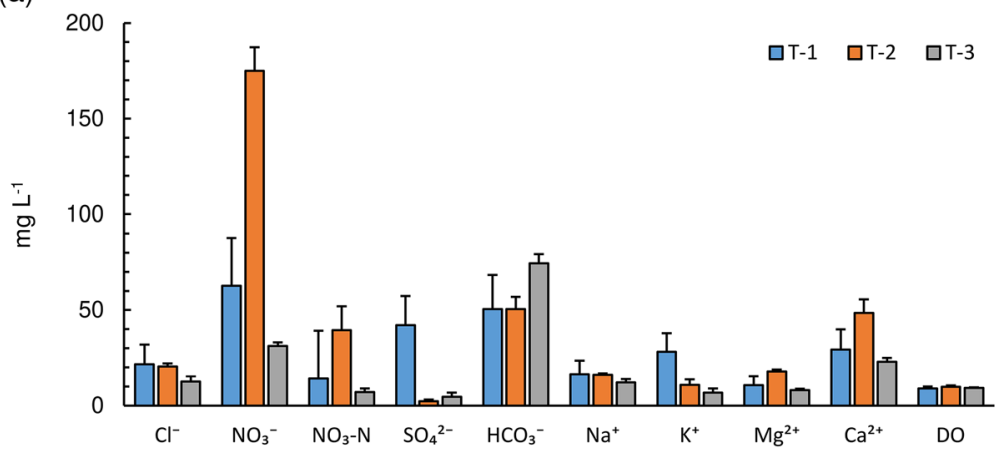

(b)

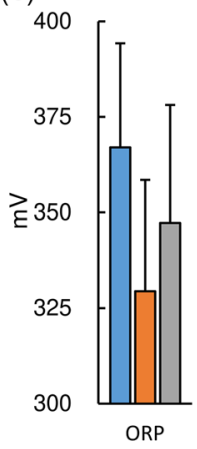

(c)

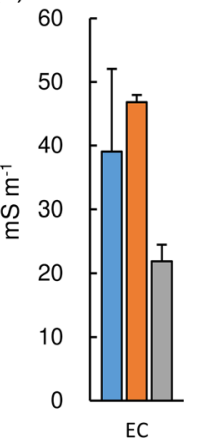

(d)

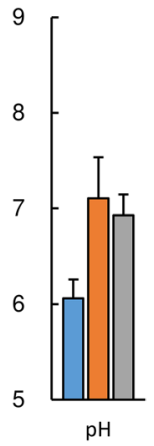

Figure 3. Chemistry of groundwater (a) Major ion components and DO, (b) ORP, (c) EC, and (d) pH.

between soil, surface water, and groundwater along the two polluted Nishikawa and Yuegawa rivers, was evaluated by projecting soil, surface water, and groundwater data vertically along the stream length within $200 \mathrm{~m}$ from the mainstream river according to the plotted dot-line area in Fig. 1. The nitrate concentrations in water and soil were projected to the straight line from T-1 to T-3 (Fig. 1). Spatial variation of nitrate concentrations in groundwater had a similar pattern as the corresponding surface water, even though groundwater samples showed slightly larger concentrations ${ }^{17,19}$. In addition to the groundwater data that we obtained in this study, groundwater data from a previous study representing mean of observations from 2011 to $2013^{17}$ were used. Surface water data were studied during $2017^{19}$ at 42 locations. In the total 13 samples were collected from Yuegawa river including tributaries. In Nishikawa river, six samples were collected. Most of the water samples were collected directly from the center sections of the rivers.

\section{Results}

Groundwater. Measured hydrochemical variables in the groundwater are summarized in Fig. 3. In addition, all analyses results for each well can be found in Supplementary Table S1. $\mathrm{Ca}^{2+}$ was the dominant cation for all sampling sites. Water samples at T- 1 and T-2 were dominated by $\mathrm{NO}_{3}{ }^{-}$while $\mathrm{HCO}_{3}{ }^{-}$was dominant at T-3. This shows that the chemical composition of groundwater in the area is $\mathrm{Ca}-\mathrm{NO}_{3}$ and $\mathrm{Ca}-\mathrm{HCO}_{3}$ type. Although, T-3 had a water chemistry of $\mathrm{Ca}-\mathrm{HCO}_{3}$ common to most shallow groundwater in Japan ${ }^{31}$, the other sites had unusual contents of some ions according to the below. $\mathrm{T}-1$ was characterized by $\mathrm{K}^{+}$with a mean concentration of $28.1 \mathrm{mg} \mathrm{L}^{-1}$. This site had the highest average $\mathrm{Cl}^{-}$corresponding to $21.6 \mathrm{mg} \mathrm{L}^{-1}$ for the three sites. T-2 had significantly higher $\mathrm{NO}_{3}-\mathrm{N}$ with an average concentration of $39.5 \mathrm{mg} \mathrm{L} \mathrm{L}^{-1}$. The average $\mathrm{DO}$ range from 9.0 to $9.8 \mathrm{mg} \mathrm{L}^{-1}$. All DO concentrations were above $5.0 \mathrm{mg} \mathrm{L}^{-1}$ indicating small pollution from organic matter ${ }^{32}$. The average ORP represented positive values from 329.4 to $367.0 \mathrm{mV}$, indicating that the groundwater is in an oxidant state. The average EC ranged from 21.9 to $46.8 \mathrm{mS} \mathrm{m}^{-1}$, reflecting the amount of dissolved ions. The average $\mathrm{pH}$ was between 6.1 and 7.1, representing slightly acidic to neutral conditions.

Temporal variation in precipitation, nitrate $\left(\mathrm{NO}_{3}-\mathrm{N}\right)$ concentration, and groundwater level are shown in Fig. 4. Mean nitrate $\left(\mathrm{NO}_{3}-\mathrm{N}\right)$ concentration in groundwater at $\mathrm{T}-1$ was $14.2 \mathrm{mg} \mathrm{L}{ }^{-1}$, which is exceeding Japanese drinking water standards $\left(10 \mathrm{mg} \mathrm{L}^{-1}\right)$. After precipitation events, a general decline in nitrate concentration was observed. A similar tendency can be seen at T-2. Mean nitrate concentration in groundwater at T-2 was $39.5 \mathrm{mg} \mathrm{L}^{-1}$, which is considerably exceeding Japanese drinking water standard. Mean nitrate concentration in groundwater at T-3 was $7.0 \mathrm{mg} \mathrm{L}^{-1}$, which is below drinking water standards, but still represents a relatively high concentration.

Temporal variation in coprostanol, cholestanol, and sterol ratio are shown in Fig. 5. The mean ratios at $\mathrm{T}-1, \mathrm{~T}-2$, and T-3 were $0.28,0.26$, and 0.10 , respectively. According to proposed criteria of sterol ratio, these values indicate "no pollution" $(<0.3)^{30}$. However, samples at all locations in December showed high sterol ratio (0.51-0.71). Samples at T-1 exceeded this criterion four times. Thus, this site is obviously affected by livestock waste. The mean concentration of coprostanol at T-1, T-2, and T-3 was 39.4, 30.0, and $3.62 \mathrm{ng} \mathrm{L}^{-1}$. T-1 and T-2 showed above or close to $30 \mathrm{ng} \mathrm{L}^{-1}$. High concentrations of coprostanol and cholestanol were detected in June at $\mathrm{T}-1$, which were $146.0 \mathrm{ng} \mathrm{L}^{-1}$ and $184.0 \mathrm{ng} \mathrm{L}^{-1}$, respectively.

Soil. Major ion concentrations in soil are shown in Fig. 6. The graphs are divided into water extracted and exchangeable fractions. Most of the nitrate ions $\left(\mathrm{NO}_{3}{ }^{-}\right)$are concentrated to the water extracted fraction. This confirms that nitrate ions are easily dissolved in soil water. Adsorbed nitrate concentrations gradually decreased from June to November at all sampling locations due to dilution by precipitation during the rainy season (Fig. 7). In Fig. 7, adsorbed nitrate corresponds to obtained nitrate from the soil by sequential extraction using water and calcium phosphate. Generally, nitrate concentrations at the soil surface are higher than those of the $50 \mathrm{~cm}$ soil depth.

Nitrate in the soil is relatively high from 29.4 to $382.7 \mathrm{mg} \mathrm{kg}^{-1}$ in samples collected at the LWDS adjacent to the livestock waste treatment plant (D2-D5). $\mathrm{Ca}^{2+}$ also shows a high concentration of $2257.4-3984.5 \mathrm{mg} \mathrm{kg}^{-1}$ at these sites. Especially at D4, samples have high $\mathrm{K}^{+}$concentration of $230.2 \mathrm{mg} \mathrm{kg}^{-1}$ at the $50 \mathrm{~cm} \mathrm{depth}$. The concentration of adsorbed nitrate is relatively high (about $200 \mathrm{mg} \mathrm{kg}^{-1}$ ) at the four sampling sites in Nishikawa River Basin (D7-D10). Especially at soil depth $50 \mathrm{~cm}$, nitrate concentration is high in the upstream area (D7: 


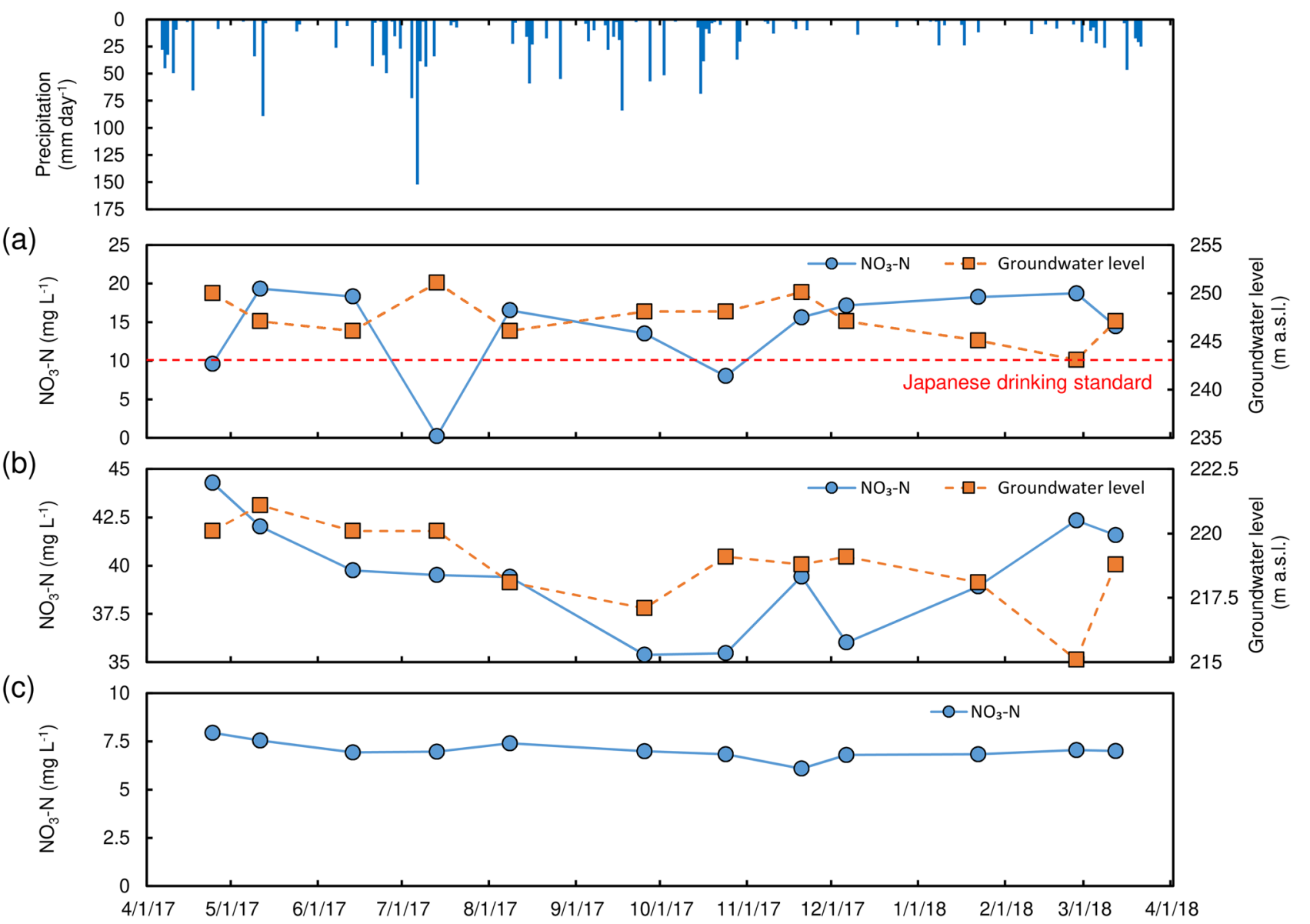

Figure 4. Temporal variation of precipitation, nitrate concentration in groundwater, and groundwater level (a) $\mathrm{T}-1$, (b) T-2, (c) T-3.

$171.9 \mathrm{mg} \mathrm{kg}^{-1}$ and D8: $\left.71.2 \mathrm{mg} \mathrm{kg}{ }^{-1}\right)$. The ammonium $\left(\mathrm{NH}_{4}^{+}\right)$concentration of $20.8-59.0 \mathrm{mg} \mathrm{kg}^{-1}$ in soil along the Nishikawa River is as high as soil samples from the LWDS. A maximum ammonium concentration of $47.6 \mathrm{mg} \mathrm{L}^{-1}$ was detected in the water samples from the Nishikawa River ${ }^{19}$. If all of $\mathrm{NH}_{4}{ }^{+}$is transformed to $\mathrm{NO}_{3}{ }^{-}$, $\mathrm{NO}_{3}{ }^{-}$concentration corresponds to $164.0 \mathrm{mg} \mathrm{L}{ }^{-1}$. At the downstream (D9 and D10), cations such as $\mathrm{K}^{+}, \mathrm{Mg}^{2+}$, and $\mathrm{Ca}^{2+}$ display high concentrations of $117.0-269.2 \mathrm{mg} \mathrm{kg}^{-1}, 118.8-211.6 \mathrm{mg} \mathrm{kg}^{-1}$, and 2874.6-6562.9 $\mathrm{mg} \mathrm{kg}^{-1}$, respectively. In addition, $\mathrm{SO}_{4}{ }^{2-}$ concentration is also high, ranging from 148.4 to $203.9 \mathrm{mg} \mathrm{kg}^{-1}$. Meanwhile, at the upstream (D7 and D8), higher concentration of $\mathrm{SO}_{4}{ }^{2-}$ with $180.4-274.2 \mathrm{mg} \mathrm{kg}^{-1}$ also was present. The soil from the upland agricultural area displayed high nitrate concentration (D6) of 349.8 and $198.64 \mathrm{mg} \mathrm{kg}^{-1}$ at each depth. In addition, $\mathrm{SO}_{4}{ }^{2-}$ concentration of $1094.8 \mathrm{mg} \mathrm{kg}^{-1}$ at the $50 \mathrm{~cm}$ depth was relatively high. $\mathrm{Ca}^{2+}$ showed high values, 3662.0 and $2796.3 \mathrm{mg} \mathrm{kg}^{-1}$ at soil surface and $50 \mathrm{~cm}$ depth, respectively, similar to the LWDS soil.

Coprostanol concentrations in water leached soil samples collected in May 2017 are plotted in Fig. 8. The results clearly show that the soil in the LWDS adjacent to the livestock waste treatment plant (D2-D5) has much higher contents as compared to soils in the Nishikawa River Basin (D7-D10). Coprostanol concentration is higher for surface soils as compared to $50 \mathrm{~cm}$ depth, similarly as for nitrate concentration.

Nitrate relationships between soil, surface water, and groundwater. Nitrate concentration in the soil, surface water, and groundwater along the Nishikawa River is summarized in Fig. 9a. From the figure it is seen that there is no clear relationship between soil and water samples. However, the concentration in soil samples (D7 and D8) appears to be related to the surface water concentration in the upstream of the river ( $>3500 \mathrm{~m}$ from the river mouth). In the case of $50 \mathrm{~cm}$ soil depth, it can be seen that there is a slight tendency of higher concentration in the upstream areas. In the upstream (D7), $50 \mathrm{~cm}$ depth concentration in soil is high and close to the concentration of the surface soil. The $50 \mathrm{~cm}$ depth concentrations then gradually decrease in the downstream direction. Thus, on soil surface, pollutants are easily transported by surface runoff.

Figure $9 \mathrm{~b}$ shows the relationship between surface and groundwater as both display a high nitrate concentration along the Yuegawa River. According to the negative gradient of the regression equation, a decreasing tendency for both surface and groundwater between 6000 and $7500 \mathrm{~m}$ from the river mouth is seen ( $y$-axis shows nitrate concentration in water, and $x$-axis shows distance from the river mouth). Except for this upstream region, most of the sampling points along the river show high concentration close to or above Japanese drinking water standards. As shown in Fig. 9, nitrate concentrations in groundwater and surface water clearly show a similar tendency up to $3000 \mathrm{~m}$ along the Nishikawa River (Fig. 9a) and 6000 to $8000 \mathrm{~m}$ along the Yuegawa River (Fig. 9b). 


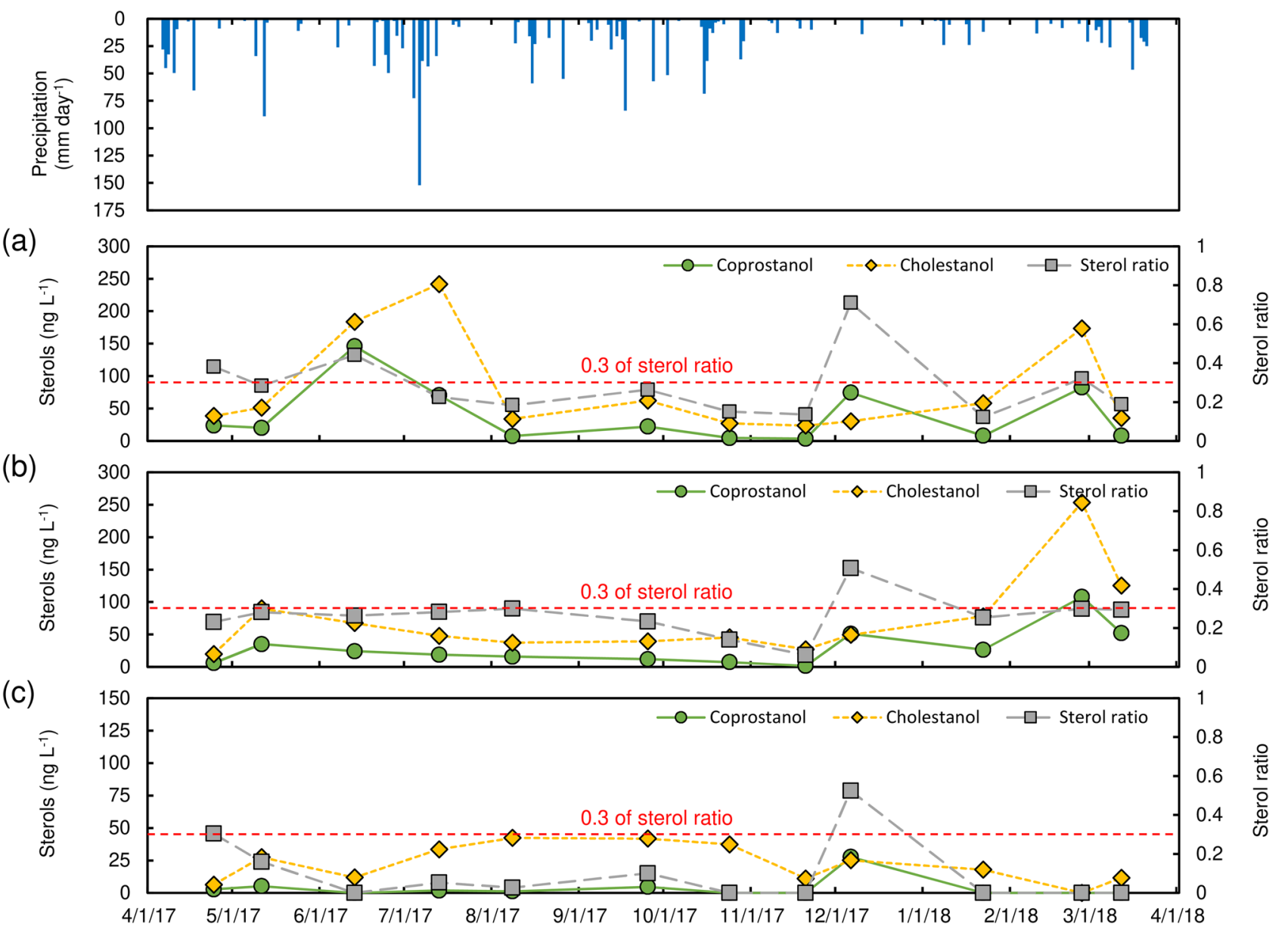

Figure 5. Temporal variation of coprostanol, cholestanol, and sterol ratio in groundwater (a) T-1, (b) T-2, (c) $\mathrm{T}-3$.

By using data at nearby locations, the correlation between surface and groundwater concentration was calculated (Fig. 10a). Accordingly, a coefficient equal to 0.93 displays a strong connection.

Similarly, nitrate concentration in soil and water is plotted along a line from T-3 to T-1 (Figs. 1 and 9c). T-2 displays a very high concentration in groundwater. This site is located at the downstream of the animal waste treatment plant. Soils contain about twice the concentration of nitrate as compared to other sites in the Nishikawa River Basin. These concentrations do not decrease in the downstream direction. The concentration $7.0 \mathrm{mg} \mathrm{L}^{-1}$ in groundwater at T-3 approximately matches the concentration $9.4 \mathrm{mg} \mathrm{L}^{-1}$ in surface water just downstream (concentrations are slightly below Japanese drinking water standard). The correlation coefficient between water (groundwater and surface water) and soil content gives 0.54 for $50 \mathrm{~cm}$ soil depth (Fig. 10b). This indicates a clear connection between soil and water content regarding nitrate.

\section{Discussion}

Groundwater. Except for T-3 with expected water chemistry, T-1 and T-2 wells represent unusually high concentration of $\mathrm{K}^{+}, \mathrm{Cl}^{-}$, and $\mathrm{NO}_{3}-\mathrm{N}$. According to the location of these wells (Fig. 1), it may be assumed that the site is affected by livestock waste from the LWDS and livestock facilities. Not only groundwater but also surface water of Yuegawa River, is severely polluted by nitrate ${ }^{19}$. Previous studies in the area have not revealed such high $\mathrm{NO}_{3}-\mathrm{N}$ concentrations ${ }^{17}$ (range of $25.8 \mathrm{mg} \mathrm{L}^{-1}$ ). The study area has a geological feature consisting of complex pyroclastic sediments on the bedrock as mentioned above. Due to this, flow paths and groundwater recharge patterns are complex potentially following structures of preferential pathways including lava tubes, faults, and fractures. Thus, spatial heterogeneity may be critical factor for nitrate transport and distribution in the study area.

Heavy precipitation corresponding to $344.5 \mathrm{~mm}$ during 9 days during the rainy season (July), increased the groundwater level and decreased nitrate concentration by dilution to $0.3 \mathrm{mg} \mathrm{L}^{-1}$ in T-1. Also other ion concentrations significantly decreased during this precipitation event from June to July as seen in Supplementary Table S1. There is a positive correlation $(r=0.72)$ between groundwater level rise and precipitation amount two weeks before the sampling date. Consequently, an inverse correlation between groundwater level and nitrate concentration is clearly present at this site. Thus, it is clear that the nitrate concentration was significantly affected by dilution from infiltrating rainfall. However, the diluted concentration was still above $35 \mathrm{mg} \mathrm{L}^{-1}$ in T-2. In T-1, 
(a)

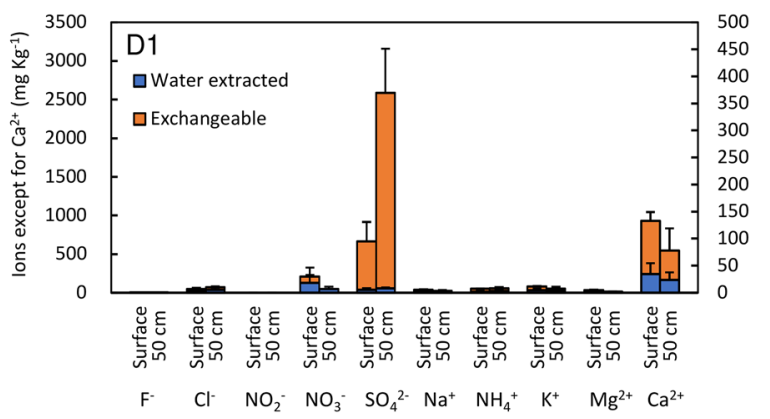

(b)

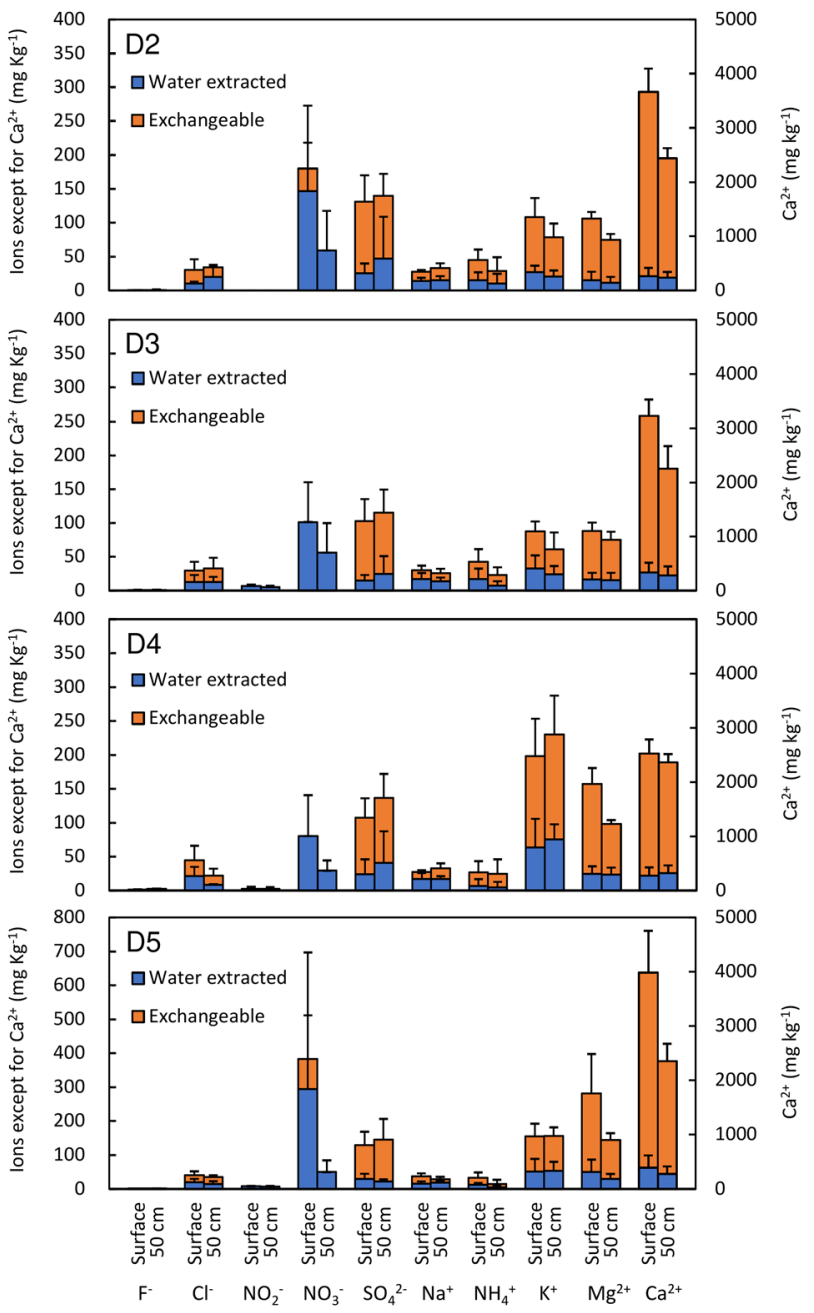

(c)

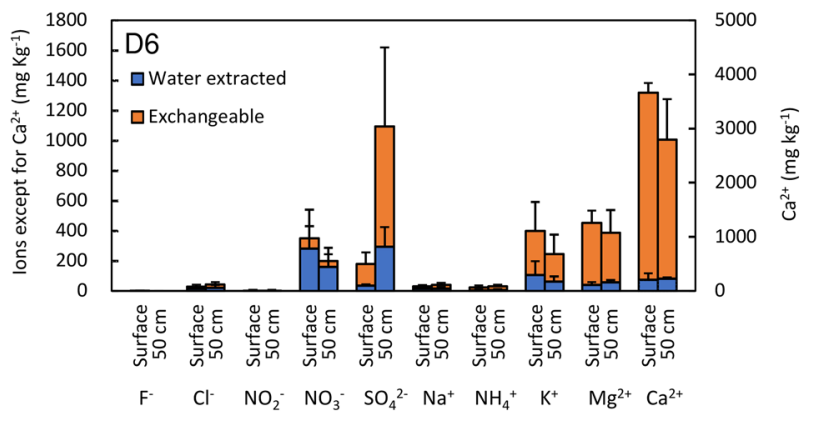

(d)
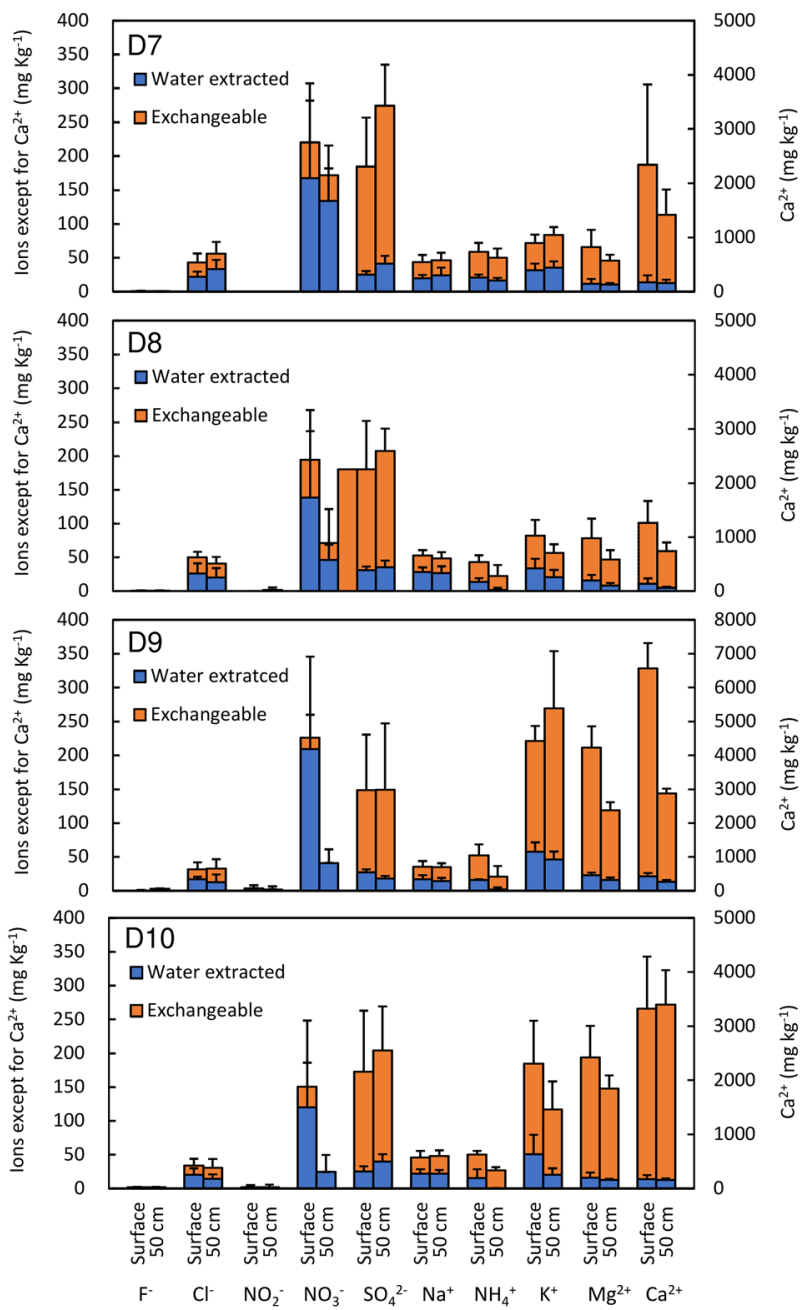

Figure 6. Major ion components in different soil types (a) forest, (b) LWDS, (c) upland field, and (d) Nishikawa River basin.

the water depth from the soil surface ranged from 27.0 to $35.0 \mathrm{~m}$. On the other hand, the water depth in T-2 ranged from 29.0 to $35.0 \mathrm{~m}$. A shallower groundwater table was usually observed in T-1 as compared to T-2. The depth of water table is an important indicator of groundwater recharge (water table rise) and dilution effect. T-2 receives water also from other livestock facilities (Fig. 1). T-2 is located about $250 \mathrm{~m}$ downstream of T-1. Since the sample of T-3 was taken from the confined aquifer, it is not affected by precipitation and thus, shows a relatively stable concentration. The location of T- 3 is $1.4 \mathrm{~km}$ downstream from T- 1.

A sterol ratio above 0.3 means that input of coprostanol into the groundwater is larger than formation of cholestanol by microbial reduction in natural environment. Increased water temperature will promote the activity of microbes ${ }^{33}$. As water temperatures were lowest in December (see Supplementary Table S1), one of the reasons for the high sterol ratio can be effects of microbe activity and introduction of cholestanol for a lower 

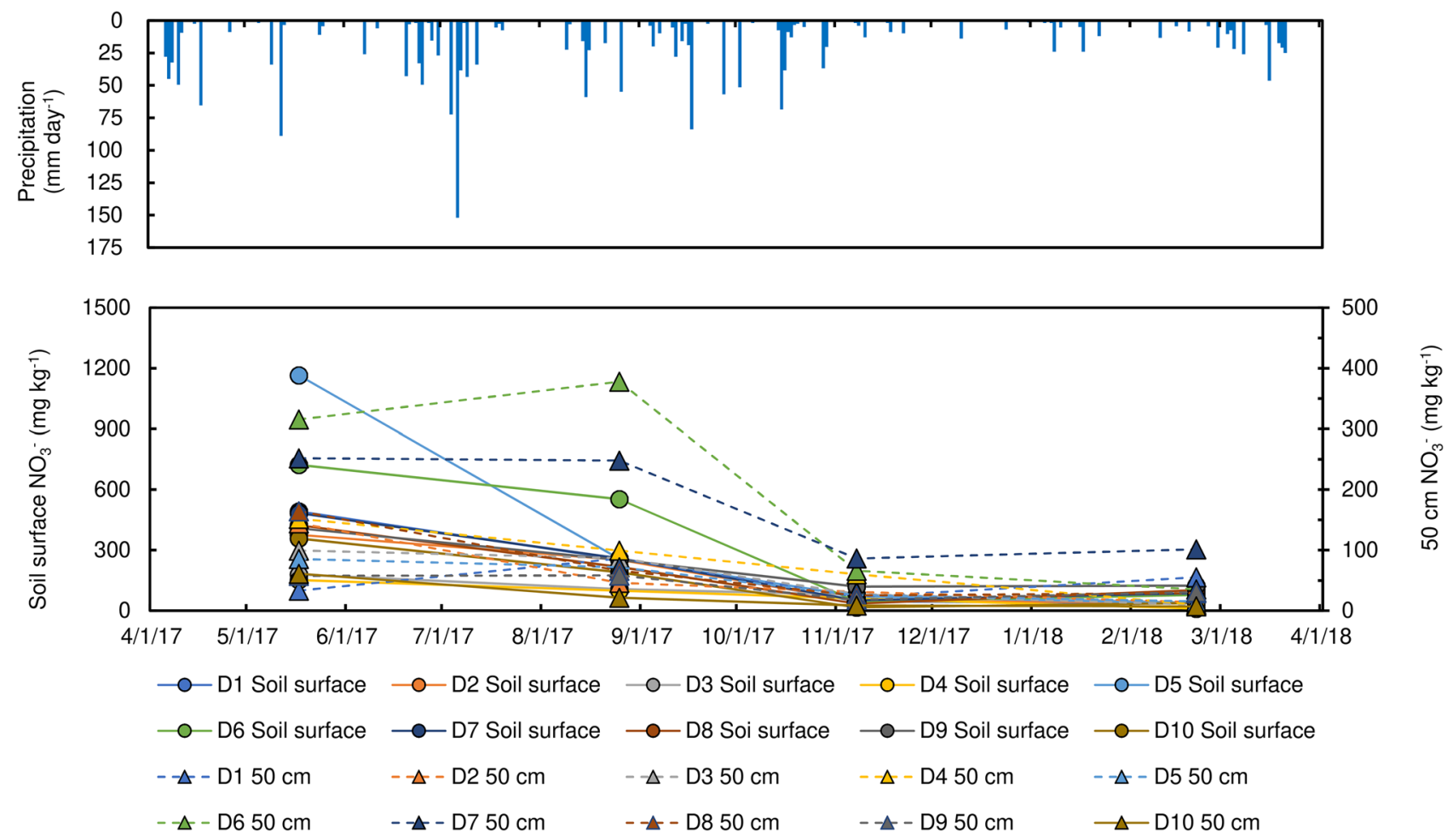

Figure 7. Temporal variation of nitrate in soil.

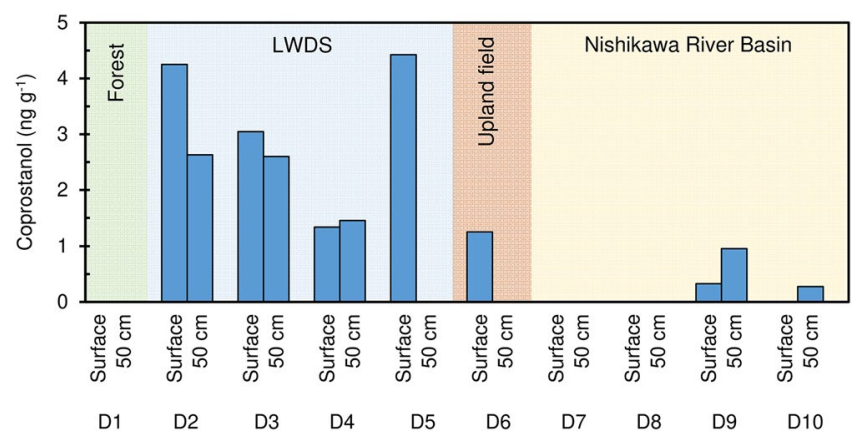

Figure 8. Water soluble coprostanol in soil (May, 2017).

water temperature. $30 \mathrm{ng} \mathrm{L}^{-1}$ is a relatively high concentration of coprostanol in groundwater. In total, 22 out of 33 coprostanol concentrations were $20.7-29.6 \mathrm{ng} \mathrm{L}^{-1}$ or undetected in a previous study in the area ${ }^{25}$. Recorded high coprostanol concentration of $146.0 \mathrm{ng} \mathrm{L}^{-1}$ in June at T-1 (Fig. 1), is obviously related to leachate of treated livestock waste. Onset of the rainy season in June promotes groundwater recharge and leachate formation. In any case, the detection of coprostanol originating from animal and human waste showed that groundwater was clearly affected by this pollution source.

Our proposed method using nitrate concentration and sterol ratio, showed that livestock waste is the main nitrate source in surface water with above $10 \mathrm{mg} \mathrm{L}^{-1}$ of nitrate and 0.3 of sterol ratio ${ }^{26}$. Nitrate and sterol ratio tended to be above or near these thresholds at sampling sites (T-1 and T-2) that are affected by livestock waste and high concentrations of $\mathrm{K}, \mathrm{Cl}$, and coprostanol. Thus, our method involving sterol ratio can be used to identify complex nitrate sources in groundwater.

Soil. Most of the nitrate ions were extracted by water. On the other hand, cations and other anions are not easily extracted by water. Thus, it may be confirmed that nitrate is easily dissolved in groundwater due to high water solubility and weak adsorption properties as summarized by Chitsazan et al. ${ }^{2}$, causing water pollution. Common for all sampling sites was that nitrate concentration at the soil surface was higher than at $50 \mathrm{~cm}$ depth. The vertical variation may reflect shallow banding of fertilizer, soil mineralization, or net upward transport of nitrate as a result of evaporation ${ }^{34}$. Nakagawa et al. $^{35}$ demonstrated by a series of soil column experiments and numerical simulation that evaporation promotes upward movement of anions. 
(a)

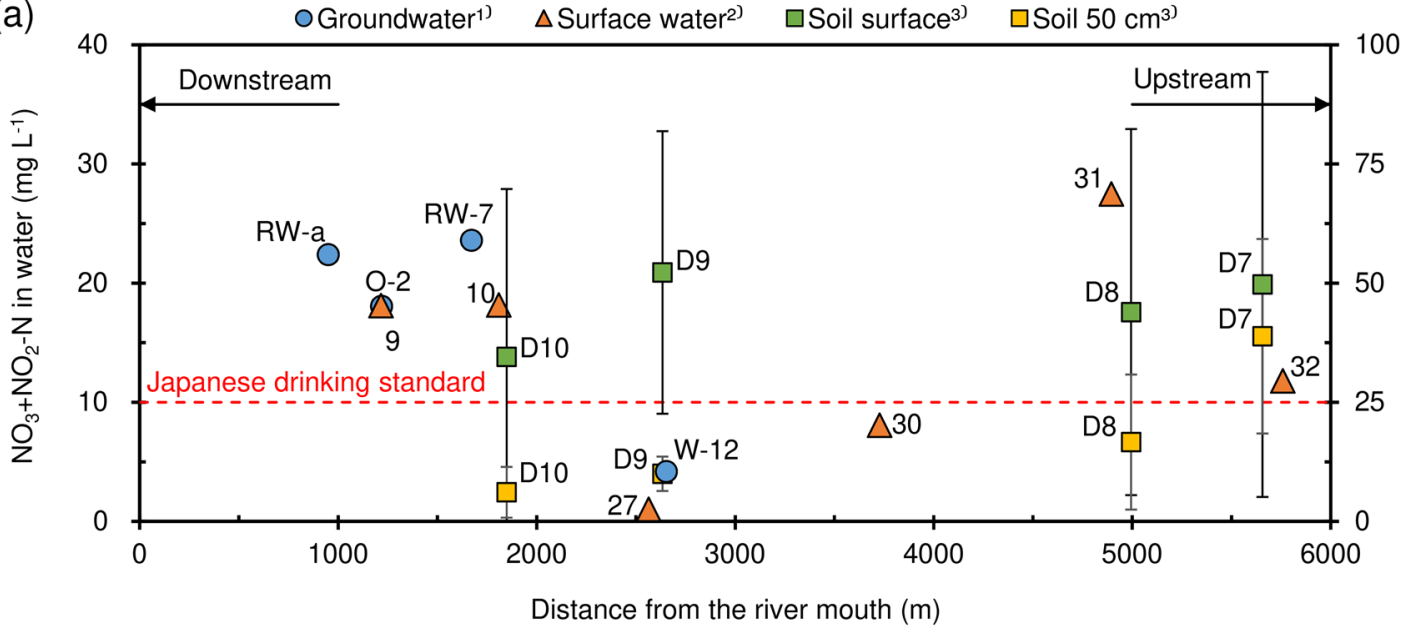

(b)

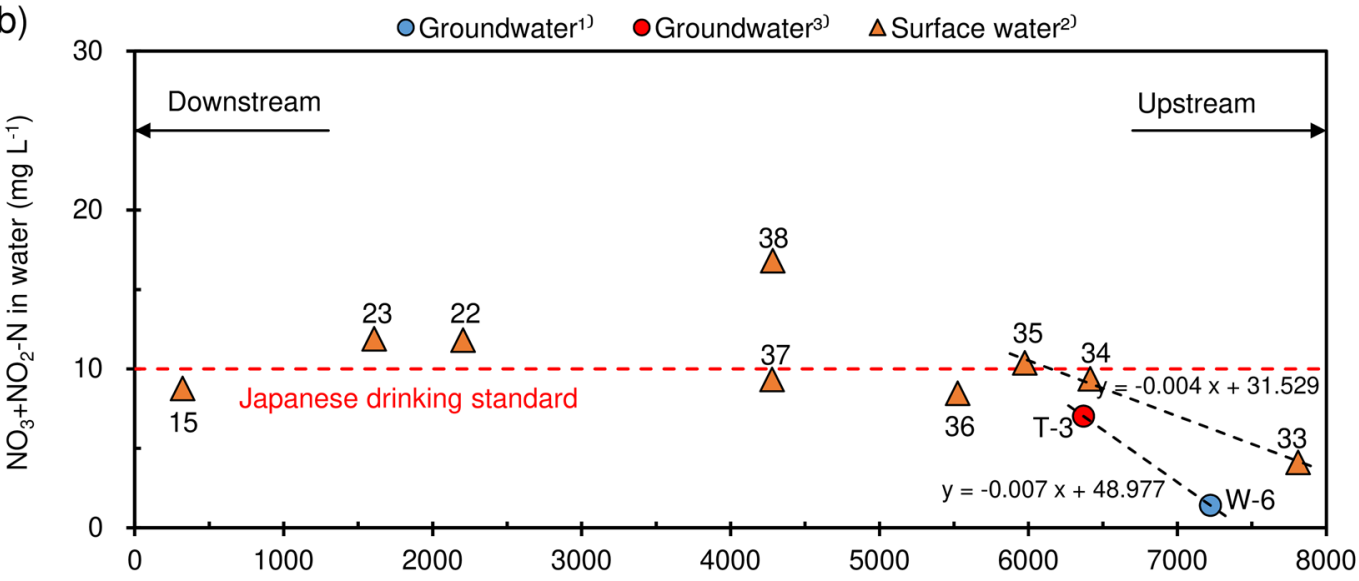

Distance from the river mouth $(\mathrm{m})$

(c)

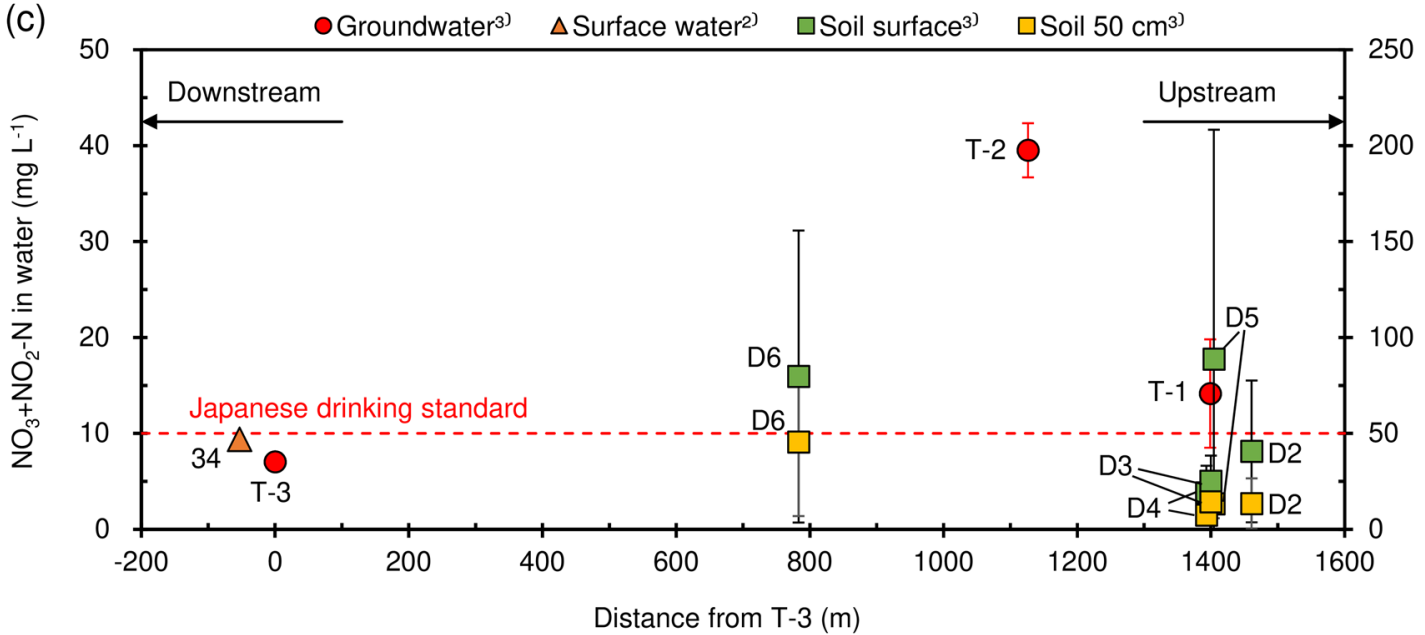

Figure 9. Distribution of nitrate concentration in soil, groundwater, and surface water (a) Nishikawa River, (b) Yuegawa River, and (c) LWDS and downstream. (1) Nakagawa et al. ${ }^{17}$, (2) Amano et al. ${ }^{19}$, (3) this study.

High nitrate content in soil is beneficial for crop cultivation, however, excess nitrate is easily leached to the groundwater due to high water solubility and weak adsorption properties as mentioned above. Depending on crop type and stage of cultivation, nitrogen demand varies. Thus, it is difficult to define a maximum permissible nitrate content in the soil. Su et al. ${ }^{10}$ estimated that background values of soil nitrate may be about $2.6 \mathrm{mg} \mathrm{kg}^{-1}$ for agricultural soils in China. All soil samples in our study area exceeded this value. Nitrate levels in surface soil were input to a regression equation between groundwater and soil nitrate suggested by Wang et al. ${ }^{9}$. As a result, the estimated nitrate $\left(\mathrm{NO}_{3}-\mathrm{N}\right)$ level in groundwater is in the range from 1.32 to $5.28 \mathrm{mg} \mathrm{L}^{-1}$. However, 

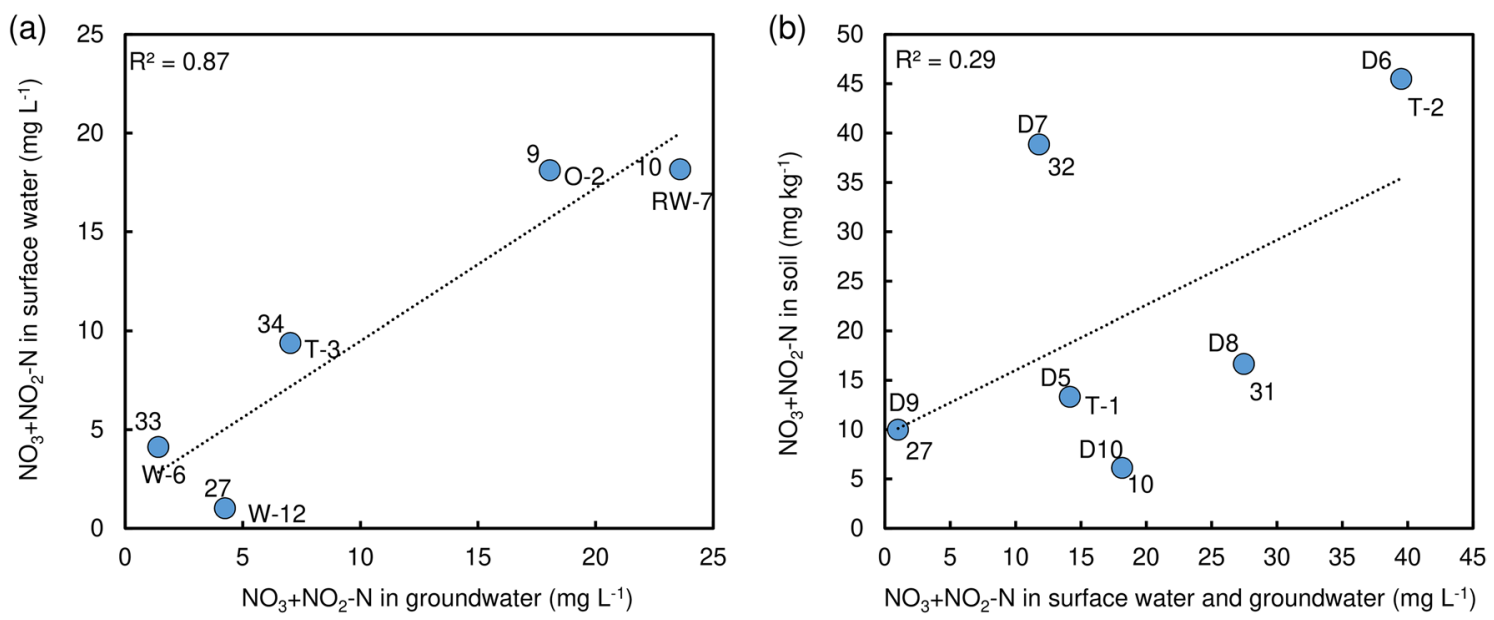

Figure 10. Nitrate concentration relationships for groundwater, surface water, and soil.

since 11 years have passed since 2006 and the closure of the LWDS, the plume of high nitrate concentrations is expected to have moved to larger soil depth. This is confirmed by the estimated nitrate concentrations that are below the Japanese drinking water standard of $10 \mathrm{mg} \mathrm{L}^{-1}$. Even so, the closed LWDS site is expected to have affected the groundwater.

There are many kinds of fertilizers used in the study area $^{36}$. One fertilizer contains specific components such as $\left(\mathrm{NH}_{4}\right)_{2} \mathrm{SO}_{4}, \mathrm{Ca}\left(\mathrm{H}_{2} \mathrm{PO}_{4}\right)_{2} \cdot \mathrm{H}_{2} \mathrm{O}+\mathrm{CaSO}_{4}$, and $\mathrm{K}_{2} \mathrm{SO}_{4}$. Another type includes $\mathrm{Mg}\left(\mathrm{H}_{2} \mathrm{PO}_{4}\right)_{2}, \mathrm{~K}_{2} \mathrm{SiO}_{3}, \mathrm{NH}_{4} \mathrm{Cl}$, and $\mathrm{KCl}$. $\mathrm{CaCO}_{3}$ are applied for disinfection of deceased animals in livestock facilities. Livestock waste includes $\mathrm{Cl}^{-}$and essential nutrients such as $\mathrm{N}, \mathrm{P}$, and $\mathrm{K}$. Thus, high nitrate, $\mathrm{Ca}^{2+}$, and $\mathrm{K}^{+}$concentration in D2-D5 (LWDS) may be related to these factors. At the downstream of Nishikawa River (D9 and D10), high potassium may also be related to the livestock waste. However, $\mathrm{Ca}^{2+}$ and $\mathrm{Mg}^{2+}$ are related to chemical fertilizers commonly applied together with $\left(\mathrm{NH}_{4}\right)_{2} \mathrm{SO}_{4}$. Probably, nitrate pollution sources are mixed with chemical fertilizers and livestock waste in the downstream area of the Nishikawa River Basin. Meanwhile, high concentration of $\mathrm{SO}_{4}{ }^{2-}$ at the upstream (D7 and D8) is also related to application of chemical fertilizers such as an ammonium sulfate, $\left(\mathrm{NH}_{4}\right)_{2} \mathrm{SO}_{4}$. This may be regarded as a major pollution source in the upstream of Nishikawa River. Relatively high concentration of $\mathrm{SO}_{4}{ }^{2-}$ and $\mathrm{Ca}^{2+}$ at $\mathrm{D} 6$ is probably also a result of fertilizer application and $\mathrm{CaCO}_{3}$ for disinfection. High $\mathrm{SO}_{4}{ }^{2-}$ concentrations of 664.3 and $2585.1 \mathrm{mg} \mathrm{kg}^{-1}$ in the forest may be naturally occurring in the soil (D1).

The high coprostanol concentrations at D2-D5 (LWDS) are due to disposed livestock waste that risk to leach nitrate to the groundwater. D6 is located in the upland agricultural area close to an animal husbandry farm and it is likely that manure has been applied here as fertilizer. Accordingly, coprostanol was detected in the soil surface at D6. Some threshold values of coprostanol have been suggested to indicate sewage contamination such as $100 \mathrm{ng} \mathrm{g}^{-1}$ in river sediments ${ }^{37}$. Accordingly, observed levels in our study indicate no sewage contamination.

Nitrate relationships between soil, surface water, and groundwater. Pollutants from not only soil but also waste water drained from pig farms affected nitrogen content in the water environment ${ }^{19}$. On the other hand, vertical transport of pollutants is slow (e.g., $0.22-0.26 \mathrm{~m} \mathrm{year}^{-1}$ for nitrate ${ }^{38}$ ) that eventually may reach larger soil depths after considerable time. These processes explain the effects of the upstream pollution sources. Even if the nitrate concentration in groundwater is below the Japanese drinking water standard $10 \mathrm{mg} \mathrm{L}^{-1}$, the soil has more or less the same high amount of nitrate along the upstream to downstream between 2500 and $4000 \mathrm{~m}$ from the river-mouth in Nishikawa River. The annual variation of nitrate concentration in the soil (Fig. 7), indicates a clear leaching tendency with precipitation. In addition, the correlation between water and soil regarding nitrate concentration, suggests risk of future increased nitrate contents in both surface and groundwater.

\section{Conclusions}

Research is needed to improve methods for distinguishing different spatiotemporal nitrate sources to soil and groundwater. The spatiotemporal variability of potential pollutant sources creates a strong complexity that is difficult to decipher using traditional methods. The common soil and geologic media complexity creates a second difficulty in this context. In practical applications it is therefore, difficult to distinguish fate and transport properties of nitrate from different overlapping pollutant sources. Thus, it is important to develop new methods that can be tested on various experimental areas and observations of nitrate concentrations.

In our study, two of three groundwater samples displayed elevated mean nitrate concentration exceeding Japanese drinking water standard $\left(10 \mathrm{mg} \mathrm{L}^{-1}\right)$. Groundwater well $\mathrm{T}-2$ displayed the highest nitrate concentration. High concentrations of nitrate are likely affected by discharged livestock waste. In this context, coprostanol occurrence showed that the groundwater is polluted by livestock waste. Nitrate concentration in soil was relatively high in samples collected at the LWDS adjacent to the livestock waste treatment plant. Even so, samples from the Nishikawa River Basin displayed higher nitrate concentration in soil as compared to the LWDS samples. In terms of $\mathrm{NH}_{4}{ }^{+}$, surface water samples collected in the Nishikawa River Basin also displayed nitrate pollution. 
There have been no remediation activities for the LWDS soil. The area is mainly affected by natural attenuation in soil and groundwater. Thus, the soil is still clearly influenced by animal waste, as indicated by the coprostanol content. Accordingly, the coprostanol content clearly displayed type of soil contamination source. Depending on the location, considering the high concentration of specific ions $\left(\mathrm{SO}_{4}{ }^{2-}\right.$, and $\left.\mathrm{K}^{+}\right)$and the detection of coprostanol, the main nitrate sources were shown to be chemical fertilizer in combination with likely influence of livestock waste in the soil and groundwater. Nitrate in groundwater and soil is diluted by precipitation during the rainy season. The dilution is notable only for the unconfined groundwater where nitrate concentration is relatively constant. Nitrate concentration in groundwater is related to the concentration in the surface water both for Nishikawa and Yuegawa River Basins. There is complex but clear relationship between soil and water samples regarding nitrate concentration and high concentration in the soil is likely to be related to the groundwater and surface water pollution. Thus, in addition to the spatial heterogeneity of pyroclastic sediments, nitrate distribution reflects soil, groundwater, and surface water linkage-processes.

The correlation between nitrate and other groundwater chemical components is essential to display the different types of nitrate source. Simultaneous assessment of coprostanol level in soil, surface and groundwater is useful to determine effects of livestock waste and risks for water pollution. In addition, sterol ratio is an effective tool to distinguish between nitrate sources for not only surface water but also groundwater. The relationship between coprostanol (sterol ratio) and nitrate is different depending on the spatial location. Including coprostanol analyses in nitrate assessment is a useful method that can be used in other areas where nitrate pollution sources are investigated.

Received: 16 January 2020; Accepted: 18 January 2021

Published online: 28 January 2021

\section{References}

1. WHO (World Health Organization). Guidelines for Drinking Water Quality 4th edn. (WHO Press, Geneva, 2011).

2. Chitsazan, M., Mohammad Rezapour Tabari, M. \& Eilbeigi, M. Analysis of temporal and spatial variations in groundwater nitrate and development of its pollution plume: a case study in Karaj aquifer. Environ. Earth Sci. 76, 391 (2017).

3. Marouane, B., Dahchour, A., Dousset, A. \& Hajjaji, S. E. Monitoring of nitrate and pesticide pollution in Mnasra, Morocco soil and groundwater. Water Environ. Res. 87(6), 567-575 (2015).

4. Zakhem, B. A. \& Hafez, R. Hydrochemical, isotopic and statistical characteristics of groundwater nitrate pollution in Damascus Oasis (Syria). Environ. Earth Sci. 74(4), 2781-2797 (2015).

5. Darwish, T. et al. Observations on soil and groundwater contamination with nitrate: a case study from Lebanon-East Mediterranean. Agric. Water Manag. 99(1), 74-84 (2011).

6. Costa, J. L. et al. Nitrate contamination of a rural aquifer and accumulation in the unsaturated zone. Agric. Water Manag. 57(1), 33-47 (2002).

7. Kaçaroğlu, F. \& Günay, G. Groundwater nitrate pollution in an alluvium aquifer, Eskişehir urban area and its vicinity, Turkey. Environ. Geol. 31, 178-184 (1997).

8. Strebel, O., Duynisveld, W. H. M. \& Böttcher, J. Nitrate pollution of groundwater in western Europe. Agric. Ecosyst. Environ. 26(3-4), 189-214 (1989).

9. Wang, Y., Li, K., Tanaka, S. T. T., Yang, D. \& Inamura, T. Soil nitrate accumulation and leaching to groundwater during the entire vegetable phase following conversion from paddy rice. Nutr. Cycl. Agroecosyst. 106(3), 325-334 (2016).

10. Su, W., Wang, H., Zhang, Y. \& Jin, H. The present situation and evaluation of nitrate pollution in soil in a regional aeration zone: using the proluvial fan agriculture irrigation district of Hunhe River in northeast China as an example. Environ. Earth Sci. 71(4), 1881-1891 (2014).

11. Tarkalson, D. D., Payero, J. O., Ensley, S. M. \& Shapiro, C. A. Nitrate accumulation and movement under deficit irrigation in soil receiving cattle manure and commercial fertilizer. Agric. Water Manag. 85(1-2), 201-210 (2006).

12. Elmi, A., Madani, A., Gordon, R., MacDonald, P. \& Stratton, G. W. Nitrate nitrogen in the soil profile and drainage water as influenced by manure and mineral fertilizer application in a Barley-Carrot production system. Water Air Soil Pollut. 160(1-4), 119-132 (2005).

13. Benbi, D. K., Biswas, C. R. \& Kalkat, J. S. Nitrate distribution and accumulation in an Ustochrept soil profile in a long term fertilizer experiment. Fertil. Res. 28(2), 173-177 (1991).

14. Huan, H., Wang, J. \& Teng, Y. Assessment and validation of groundwater vulnerability to nitrate based on a modified DRASTIC model: a case study in Jilin City of northeast China. Sci. Total Environ. 440, 14-23 (2012).

15. Kessasra, F. et al. Combined hydrogeological and nitrate modelling to manage water resources of the Middle Soummam Aquifer, Northeast of Algeria. Arab. J. Geosci. 10, 368 (2017).

16. Sieczka, A., Bujakowski, F., Falkowski, T. \& Koda, E. Morphogenesis of a floodplain as a criterion for assessing the susceptibility to water pollution in an agriculturally rich valley of a lowland river. Water 10, 399 (2018).

17. Nakagawa, K., Amano, H., Asakura, H. \& Berndtsson, R. Spatial trends of nitrate pollution and groundwater chemistry in Shimabara, Nagasaki, Japan. Environ. Earth Sci. 75, 234 (2016).

18. Amano, H., Nakagawa, K. \& Berndtsson, R. Groundwater geochemistry of a nitrate contaminated agricultural site. Environ. Earth Sci. 75, 1145 (2016).

19. Amano, H., Nakagawa, K. \& Berndtsson, R. Surface water chemistry and nitrate pollution in Shimabara, Nagasaki, Japan. Environ. Earth Sci. 77, 354 (2018).

20. Nakagawa, K., Watanabe, T. \& Amano, H. Potential map accuracy of groundwater nitrate load from agricultural activities in Shimabara City, Nagasaki Prefecture, Japan. J. Groundw. Hydrol. 57(4), 483-493 (2015) (in Japanese with English abstract).

21. Vystavna, Y. et al. Determination of dominant sources of nitrate contamination in transboundary (Russian Federation/Ukraine) catchment with heterogeneous land use. Environ. Monit. Assess. 189, 509 (2017).

22. Jin, Z., Qin, X., Chen, L., Jin, M. \& Li, F. Using dual isotopes to evaluate sources and transformations of nitrate in the West Lake watershed, eastern China. J. Contam. Hydrol. 177-178, 64-75 (2015).

23. Pastén-Zapata, E., Ledesma-Ruiz, R., Harter, T., Ramírez, A. I. \& Mahlknecht, J. Assessment of sources and fate of nitrate in shallow groundwater of an agricultural area by using a multi-tracer approach. Sci. Total Environ. 470-471, 855-864 (2014).

24. Diédhiou, M. et al. Tracing groundwater nitrate sources in the Dakar suburban area: an isotopic multi-tracer approach. Hydrol. Process. 26(5), 760-770 (2012).

25. Nakagawa, K., Amano, H., Takao, Y., Hosono, T. \& Berndtsson, R. On the use of coprostanol to identify source of nitrate pollution in groundwater. J. Hydrol. 550, 663-668 (2017). 
26. Nakagawa, K., Hiroki, A., Berndtsson, R., Takao, Y. \& Hosono, T. Use of sterols to monitor surface water quality change and nitrate pollution source. Ecol. Ind. 107, 105534 (2019).

27. Japan Meteorological Agency. Weather observation data https://www.data.jma.go.jp/obd/stats/etrn/index.php (2019).

28. Murakami, T. Hydrogeological map of Shimabara Peninsula 1:50,000. Geological Survey of Japan 25 (1975). (in Japanese).

29. Furukawa, H. The foot of Unzen, Groundwater in Kyushu region, Regional groundwater in Groundwater in Japan (ed. Editing committee of Groundwater in Japan in Agricultural groundwater research group) 824-828 (Chikyusya, 1986). (in Japanese).

30. Bujagić, I. M., Grujić, S., Jauković, Z. \& Laušević, M. Sterol ratios as a tool for sewage pollution assessment of river sediments in Serbia. Environ. Pollut. 213, 76-83 (2016).

31. Yabusaki, S. Characteristics and usage of groundwater chemistry and stable isotopes in Science of groundwater and water circulation (ed. Takamura, H.) 41-68 (Kokonshoin, 2011). (in Japanese).

32. Nirbahavane, G. \& Khobragade, K. Study of dissolved oxygen present in the groundwater around Ambernath area. Int. J. Adv. Eng. Res. Dev. 4(8), 21-23 (2017).

33. Reeves, A. D. \& Patton, D. Faecal sterols as indicators of sewage contamination in estuarine sediments of the Tay Estuary, Scotland: an extended baseline survey. Hydrol. Earth Syst. Sci. 9, 81-94 (2005).

34. Zebarth, B. A. \& Milburn, P. H. Spatial and temporal distribution of soil inorganic nitrogen concentration in potato hills. Can. J. Soil Sci. 83(2), 183-195 (2003).

35. Nakagawa, K. et al. Modelling reactive solute transport from groundwater to soil surface under evaporation. Hydrol. Process. 24, 608-617 (2010).

36. National Federation of Agricultural Cooperative Associations (ZEN-NOH). Operated Fertilizers Safety Data Sheets. https://www. zennoh.or.jp/operation/hiryou/sds/corporate/k4.html (2020).

37. Martins, C. D. C., Fillmann, G. \& Montone, R. C. Natural and anthropogenic sterols inputs in surface sediments of Patos Lagoon, Brazil. J. Braz. Chem. Soc. 18(1), 106-115 (2007).

38. Baran, N., Richert, J. \& Mouvet, C. Field data and modelling of water and nitrate movement through deep unsaturated loess. J. Hydrol. 345(1-2), 27-37 (2007).

\section{Acknowledgements}

The authors express their gratitude to the Environmental Department of Nagasaki Prefectural Government for help with field sampling. This work was supported by JSPS KAKENHI under Grant Numbers JP16KK0014 and JP20K12209.

\section{Author contributions}

K.N. designed the study and acquired the grant. H.A. carried out the chemical analysis. K.N. and H.A. wrote the paper and prepared all figures and supplementary table. M.P. and R.B. contributed to discussion of results. All authors reviewed and revised the paper. R.B. did the final language editing.

\section{Competing interests}

The authors declare no competing interests.

\section{Additional information}

Supplementary Information The online version contains supplementary material available at https://doi. org/10.1038/s41598-021-82188-2.

Correspondence and requests for materials should be addressed to K.N.

Reprints and permissions information is available at www.nature.com/reprints.

Publisher's note Springer Nature remains neutral with regard to jurisdictional claims in published maps and institutional affiliations.

Open Access This article is licensed under a Creative Commons Attribution 4.0 International License, which permits use, sharing, adaptation, distribution and reproduction in any medium or format, as long as you give appropriate credit to the original author(s) and the source, provide a link to the Creative Commons licence, and indicate if changes were made. The images or other third party material in this article are included in the article's Creative Commons licence, unless indicated otherwise in a credit line to the material. If material is not included in the article's Creative Commons licence and your intended use is not permitted by statutory regulation or exceeds the permitted use, you will need to obtain permission directly from the copyright holder. To view a copy of this licence, visit http://creativecommons.org/licenses/by/4.0/.

(C) The Author(s) 2021 